\title{
IGF-IR: a new prognostic biomarker for human glioblastoma
}

\author{
C Maris ${ }^{1}$, N D’Haene ${ }^{1}$, A-L Trépant ${ }^{1}$, M Le Mercier ${ }^{1}$, S Sauvage ${ }^{2}$, J Allard ${ }^{1}$, S Rorive ${ }^{1,2}$, P Demetter ${ }^{1}$, \\ C Decaestecker ${ }^{2,3}$ and I Salmon ${ }^{*} 1,2$ \\ ${ }^{1}$ Department of Pathology, Erasme University Hospital, Université Libre de Bruxelles (ULB), Brussels 1070, Belgium; ${ }^{2}$ DIAPath, \\ Center for Microscopy and Molecular Imaging (CMMI), Académie Universitaire Wallonie-Bruxelles, Gosselies 6041, Belgium and \\ ${ }^{3}$ Laboratories of Image, Signal processing and Acoustics (LISA), Brussels School of Engineering/Ecole Polytechnique de Bruxelles, \\ Université Libre de Bruxelles (ULB), Brussels 1050, Belgium
}

Background: Glioblastomas (GBMs) are the most common malignant primary brain tumours in adults and are refractory to conventional therapy, including surgical resection, radiotherapy and chemotherapy. The insulin-like growth factor (IGF) system is a complex network that includes ligands (IGFI and IGFII), receptors (IGF-IR and IGF-IIR) and high-affinity binding proteins (IGFBP-1 to IGFBP-6). Many studies have reported a role for the IGF system in the regulation of tumour cell biology. However, the role of this system remains unclear in GBMs.

Methods: We investigate the prognostic value of both the IGF ligands' and receptors' expression in a cohort of human GBMs. Tissue microarray and image analysis were conducted to quantitatively analyse the immunohistochemical expression of these proteins in 218 human GBMs.

Results: Both IGF-IR and IGF-IIR were overexpressed in GBMs compared with normal brain $\left(P<10^{-4}\right.$ and $P=0.002$, respectively). Moreover, with regard to standard clinical factors, IGF-IR positivity was identified as an independent prognostic factor associated with shorter survival $(P=0.016)$ and was associated with a less favourable response to temozolomide.

Conclusions: This study suggests that IGF-IR could be an interesting target for GBM therapy.

Glioblastoma (GBM) is the most common malignant primary brain tumour in adults, accounting for approximately $12-15 \%$ of all intracranial neoplasms (Louis et al, 2007). Despite the progress made in surgery, radiotherapy and chemotherapy, the overall survival of patients with GBM remains poor, with a 5-year survival rate of 3.3\% (Bondy et al, 2008).

Several studies identified subtypes of GBM associated with different prognoses or responses to treatment (Phillips et al, 2006; Verhaak et al, 2010; Le Mercier et al, 2012). To develop novel targeted therapies and improve patient outcome, it is imperative to better understand the molecular mechanisms involved in GBM pathogenesis and to identify new biomarkers associated with prognostic values and/or predictive of the response to treatment.

The insulin-like growth factor (IGF) system has a crucial role in tumorigenesis owing to its involvement in apoptosis, mitogenesis, cell migration, multidrug resistance and radioresistance (Guvakova, 2007; Samani et al, 2007). This system consists of soluble ligands (including IGFI and IGFII), cell surface transmembrane receptors (including IGFI receptor (IGF-IR) and IGFII receptor (IGF-IIR)) and soluble binding proteins (IGFBP1 (IGF binding protein-1) through IGFBP-6). The biological activities of IGFs are mediated by cell surface receptors and modulated by complex interactions with binding proteins (Le Roith, 2003; Denley et al, 2005; Sachdev and Yee, 2007).

Involvement of the IGF system in GBM pathogenesis is widely supported in the literature. The presence of IGF-IR and IGF-IIR in GBM cell lines has been demonstrated (Friend et al, 2001; Schlenska-Lange et al, 2008). In vitro, IGFs were shown to promote proliferation, survival and migration of GBM cell lines (Friend et al, 2001; Brockmann et al, 2003; Soroceanu et al, 2007; 
Rorive et al, 2008; Schlenska-Lange et al, 2008). However, reports on the expression of the members of the IGF system in human GBM samples are often limited to small series and thus have not yielded consistent results. Although IGFI expression was observed in the majority of GBMs (Antoniades et al, 1992; SandbergNordqvist et al, 1993; Hirano et al, 1999) using in situ hybridisation (100\%) or immunohistochemistry (75-100\%), IGFII expression was less prevalent, detectable in only $6 \%$ of GBMs using in situ hybridisation (Soroceanu et al, 2007) and in 58\% using immunohistochemistry (Suvasini et al, 2011). In contrast, Suvasini et al (2011) reported that IGFI and IGFII transcript levels evaluated by RT-qPCR do not change between normal brain samples and grade II astrocytomas, grade III astrocytomas and GBMs. Several studies demonstrated IGF-IR expression in the majority of GBM samples analysed by means of in situ hybridisation, binding assays or western blotting (Glick et al, 1989; Merrill and Edwards, 1990; Antoniades et al, 1992; Yin et al, 2010), whereas RT-qPCR demonstrated no significant difference in the transcript levels of normal brain samples and low- and high-grade astrocytomas (Suvasini et al, 2011). Literature data on IGF-IIR expression are scarce (Antoniades et al, 1992; Friend et al, 2001; Schlenska-Lange et al, 2008).

Considering the results of in vitro studies and the expression of IGF-IR in the majority of GBMs, it is surprising that little data are available concerning the clinical significance of the IGF system in GBM. To the best of our knowledge, only two studies have reported the prognostic value of the IGF system in GBM. Using gene expression analysis, Soroceanu et al (2007) identified a group of GBMs characterised by IGFII overexpression and belonging to a subclass associated with poor survival. Furthermore, a recent study showed an inverse correlation between IGF-IR gene and protein expression levels and survival (Zamykal et al, 2014). Therefore, our goal was to evaluate the prognostic value of the IGF ligands (IGFI and IGFII) and their receptors (IGF-IR and IGF-IIR) in a large series of GBMs using quantitative immunohistochemistry based on image analysis of tissue microarray (TMA) materials.

\section{MATERIALS AND METHODS}

Clinical and histopathological data. Two normal brain TMAs were manufactured using formalin-fixed and paraffin-embedded samples from nine post mortem adult human brains (without neuropathological alterations) obtained within $24 \mathrm{~h}$ of death. Six tissue cores (diameter: $600 \mu \mathrm{m}$ ) were taken from six different areas per brain: grey and white matter from the cerebral hemispheres (frontal and occipital lobes), corpus callosum, and semioval center. A series of 218 GBMs was investigated in parallel. The series consisted of archival formalin-fixed and paraffin-embedded samples obtained from the Laboratory of Pathology of the Erasme University Hospital (Brussels, Belgium) that were collected between 1988 and 2006. All the samples were surgical specimens obtained by open surgical resection. Four TMAs that included three tissue cores (diameter: $600 \mu \mathrm{m}$ ) per case and that targeted the tumour bulk were produced. All of the tumours were classified by two pathologists (SR/IS) according to the 2007 revised World Health Organisation classification system (Louis et al, 2007). This study received the approval of the Ethics Committee of the Université Libre de Bruxelles Hôpital Erasme. According to the Belgian law of December 2008 'Loi relative à l'obtention et à l'utilisation de matériel corporel humain destine à des applications médicales humaines ou à des fins de recherche scientifique', no written informed consent was required. The Ethics Committee has thus waived the need for written informed consent from the participants.
The available clinical data for each patient included age, gender, multifocality of the tumour, date of surgery, extent of surgical resection, adjuvant treatment and follow-up (Table 1). The cancerspecific survival period was measured from the date of tumour surgery until the date of death due to tumour progression.

Immunohistochemistry. As previously described (Rorive et al, 2010), standard immunohistochemistry was performed on $5-\mu \mathrm{m}$ thick sections (one per antibody) to assess the expression of IGFI, IGFII, IGF-IR and IGF-IIR, using a mouse monoclonal antibody (anti-IGFI; sc-74116; dilution 1:25, Santa Cruz Biotechnology, Santa Cruz, CA, USA), rabbit polyclonal antibodies (anti-IGFII; ab9574, dilution 1:400; Abcam, Cambridge, UK and anti-IGF-IIR; sc-25462; dilution 1:100; Santa Cruz Biotechnology), and a rabbit monoclonal antibody (anti-IGF-IR; 790-4346, RTU; Ventana Medical System, Tucson, AZ, USA).

Immunohistochemical staining was visualised using streptavidinbiotin-peroxidase complex kit reagents (BioGenex, San Ramon, CA, USA) with diaminobenzidine $/ \mathrm{H}_{2} \mathrm{O}_{2}$ as chromogenic substrate. Counterstaining with hematoxylin concluded the processing. Negative controls were prepared by replacing the primary antibodies with non-immune serum (Dako, Glostrup, Denmark). As previously described (Battifora, 1991; Decaestecker et al, 2009), additional technical and fixative controls were carried out by staining the TMA slides with haematoxylin-eosin and antivimentin (V-9, dilution 1:100; BioGenex), respectively. The final validation stage (conducted by two pathologists (CM/SR)) aimed to confirm the adequacy of the specific tumour zones targeted and immunostaining compliance. Only the cores that satisfied all of the control staining tests were submitted for quantification (Decaestecker et al, 2009).

Evaluation of immunohistochemical staining. TMA core image acquisition and staining quantification were performed using SpotBrowser V2e (Alphelys, Plaisir, France) connected to a DXC-390 Sony camera and a motorised stage (Marzhaüser, Wetzlar-Steindorf, Germany) on a BX50 Olympus microscope (Olympus, Aartselaar, Belgium), as previously described (Decaestecker et al, 2009; Rorive et al, 2010). For each valid core, we measured the analysed (i.e., positive and negative) tissue area and the positive (i.e., stained) area. To characterise each normal or GBM case, we pooled all of the appropriate cores and computed the labelling index (LI), which is the percentage of the immunostained tissue area (Decaestecker et al, 2009). To discriminate between GBM showing no expression from those with expression, the cutoff value of $1 \%$ was used (i.e., negative $\mathrm{LI}<1 \% v s$ positive $\mathrm{LI} \geqslant 1 \%$ ). In addition, we took into account that using a higher cutoff decreases interobserver variability in the interpretation of immunohistochemical analysis and that $30 \%$ is a threshold relatively easy to interpret in clinical applications (Hameed et al, 2008). A refined three-class system was thus also used for IGF-IR LI: negative $(\mathrm{LI}<1 \%)$, weakly positive $(1 \% \leqslant \mathrm{LI}<30 \%)$, and strongly positive ( $\mathrm{LI} \geqslant 30 \%)$.

To evaluate colocation of ligands and receptors in GBM samples, we analysed the expression of the different proteins inside the same TMA core and across the different sections submitted to immunohistochemistry. For this purpose, we selected the cores showing ligand (IGFI or IGFII) expression and satisfying all of the control staining tests for the expression of the two receptors (IGF-IR and IGF-IIR) to be able to evaluate the proportion of cores showing receptor expression.

Statistical analyses. All of the statistical analyses were performed using Statistica software (Statsoft, Tulsa, OK, USA). Comparisons between two independent groups of numerical data were performed using the non-parametric Mann-Whitney test. The association between two binary variables was assessed using the Exact Fisher test. Univariate survival analyses were performed 
Table 1. Clinical data for 218 patients

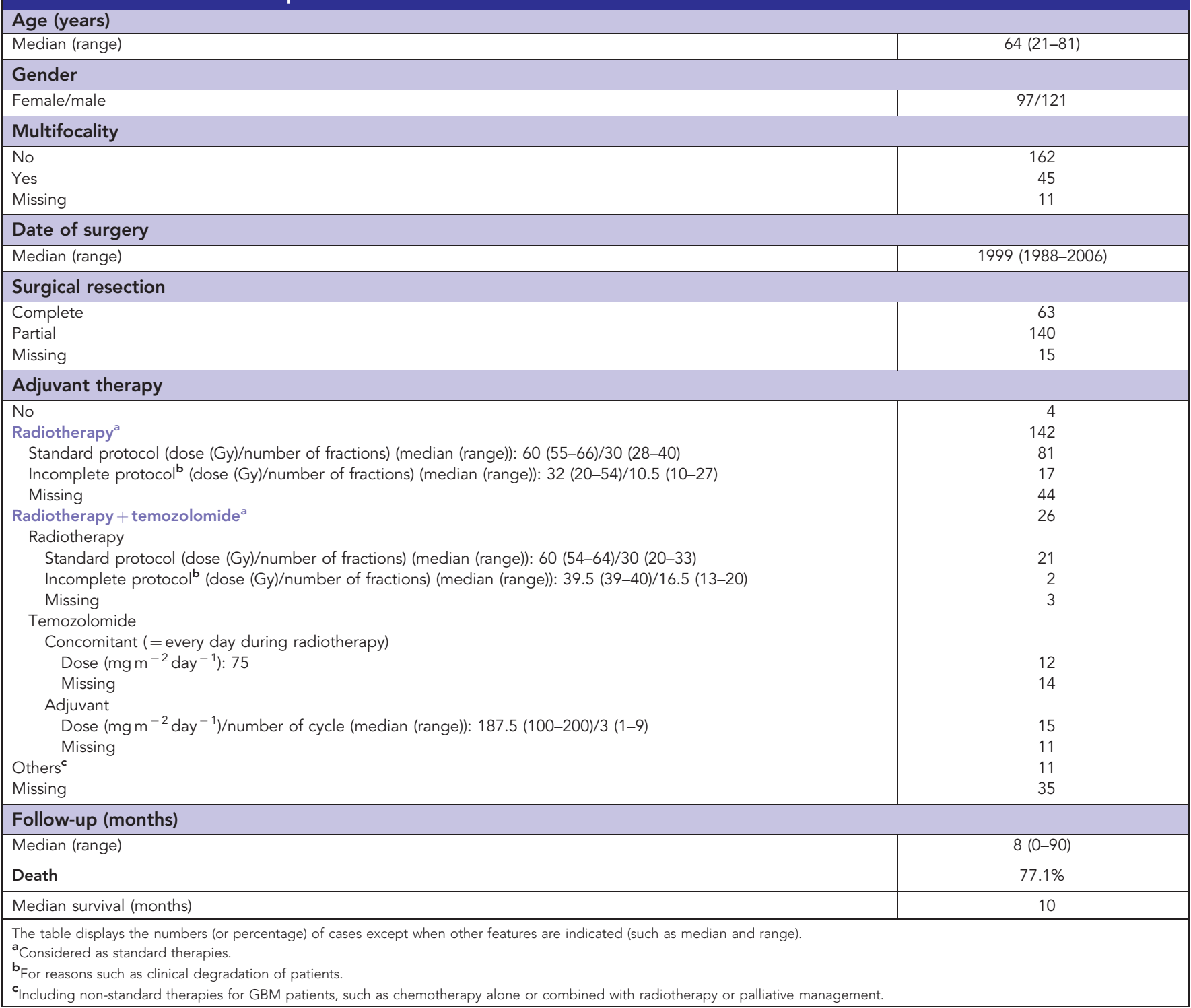

using the standard Kaplan-Meier analysis and the log-rank test (or its generalisation for $>2$ groups), except in cases of continuous variables, for which univariate Cox regression was used. We completed these analyses using multivariate Cox regression. Missing values were excluded from any analysis and $P$-values $<0.05$ were considered as being significant.

\section{RESULTS}

IGF-IR and IGF-IIR are overexpressed in GBMs compared with normal brain tissue. Quantitative evaluations of the IGFI, IGFII, IGF-IR and IGF-IIR expression levels are shown in Figure 1, and the immunohistochemical stainings are illustrated in Figure 2.

The nine cases of normal adult brains ( 54 samples) presented negative expression $(\mathrm{LI}<1 \%)$ for each of the four investigated markers (Figures 1A-D), although we observed scattered staining in the cytoplasm of a few neurons, microglial or endothelial cells.

The majority of the GBMs showed no expression of IGFI (159 out of 212, i.e., $75 \%$; Figure 2A) and/or IGFII (160 out of 204, i.e., $78 \%$; Figure 2C). For the 53 cases characterised by positive expression of IGFI, the LI ranged between $1 \%$ and $35 \%$
(Figure 1A). Cytoplasmic IGFI staining was observed mainly in tumour cells and some endothelial cells (Figure 2B). IGFII expression was observed in 44 cases, with a LI ranged between $1 \%$ and $18 \%$ (Figure 1B). As was the case for the IGFI staining, cytoplasmic IGFII staining was detected in tumour cells (Figure 2D). These IGFII-positive tumour cells were often located in perinecrotic areas, that is, expressed by neoplastic cells just beside necrotic areas. In contrast to the IGFI staining results, we did not observe IGFII expression in endothelial cells. Given the small number of GBMs with positive staining for IGFI and/or IGFII, the IGFI and IGFII expression levels in the GBM tissues were not statistically different from those of normal brain tissue (Figures $1 \mathrm{~A}$ and $\mathrm{B}$ ).

Whereas a large majority of the GBM cases were IGFI- and IGFII-negative, 64\% (139 out of 218) of them showed IGF-IR expression, with a LI ranged between $1 \%$ and $73 \%$ (Figure 1C). IGF-IR staining was detected in the cytoplasm of the tumour cells and membranous staining was observed in a few of them, whereas the endothelial cells were negative (Figure 2F). Cytoplasmic IGF-IIR staining was also observed in tumour cells (Figure $2 \mathrm{H}$ ) in $51 \%$ (109 out of 213 ) of the GBMs, with a LI ranged between $1 \%$ and $43 \%$ (Figure 1D). Interestingly, we also observed cytoplasmic dot-like staining in endothelial cells. This staining pattern was 

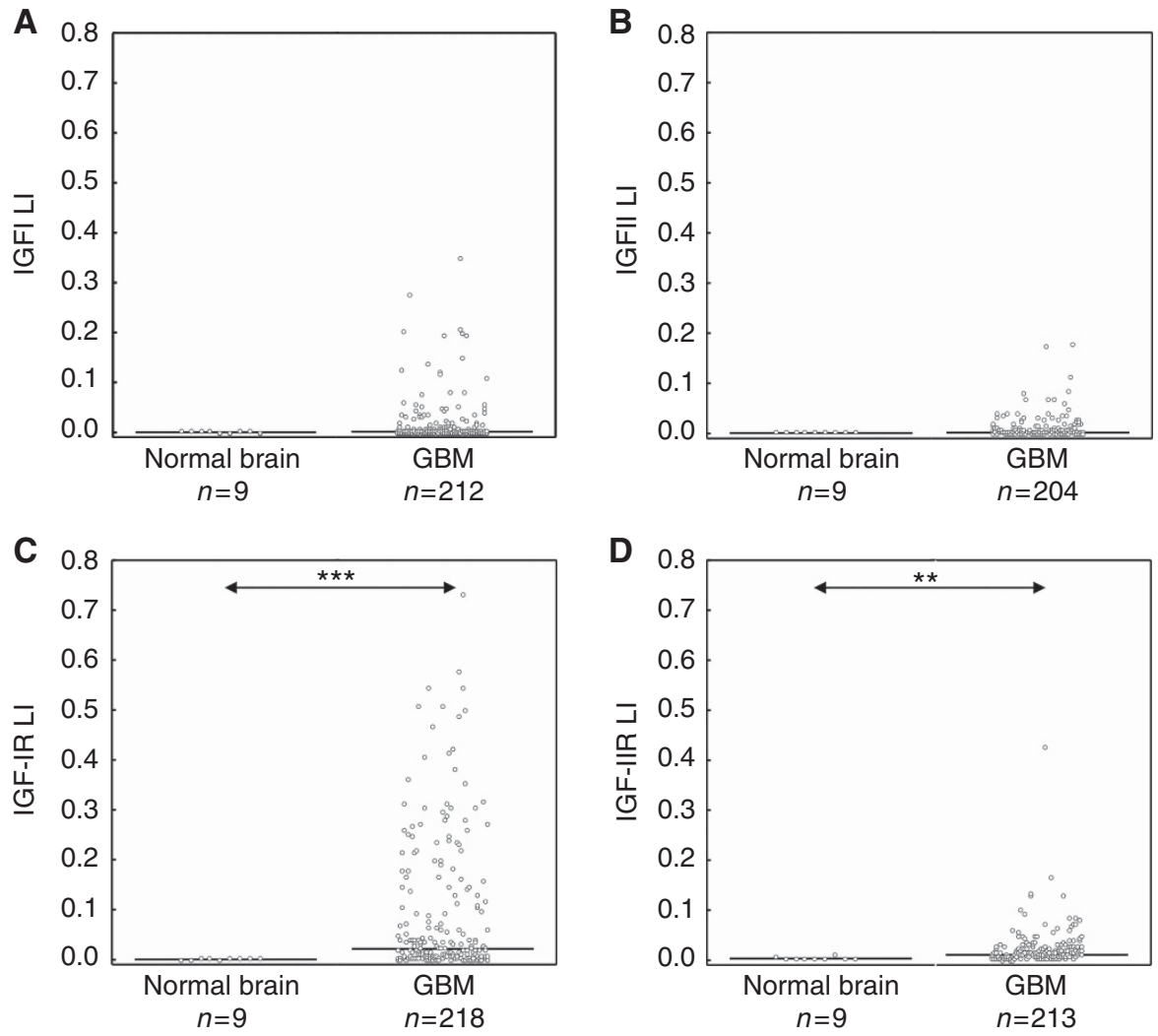

Figure 1. Quantitative evaluation of the tissue area exhibiting IGFI (A), IGFII (B), IGF-IR (C) or IGF-IIR (D) immunopositivity (LI, labelling index) in normal brain and glioblastoma samples. Each dot shows the value associated with one case. The horizontal line corresponds to the median. Only the significant differences are indicated as ${ }^{\star \star} P<0.01$ and ${ }^{\star \star \star} P<0.001$

detected mainly in tumour microvessels exhibiting endothelial proliferation (Figure 2G). The IGF-IR and IGF-IIR expression levels in the GBMs were significantly greater than those of normal brain tissue $\left(P<10^{-4}\right.$ and $P=0.002$, respectively; Figures $1 C$ and $\left.\mathrm{D}\right)$. Concerning the colocation of ligand and receptor expression in GBM samples, among the cores showing IGFI expression and analysable for receptor expression $(n=76)$, we observed $82 \%$ IGF-IR-positive cores (i.e., 62 out of 76), 59\% IGF-IIR-positive cores (i.e., 45 out of 76 ) and $51 \%$ cores positive for both receptors (39 out of 76). IGFII expression was detected in 63 cores where both receptor expression levels were analysable. Of them, 51\% (i.e., 32 out of 63) exhibited IGF-IR expression, $65 \%$ (41 out of 63 ) IGF-IIR expression and 33\% (21 out of 63) the expression of both.

IGF-IR is a prognostic marker. First, we analysed the impact of the clinical factors (listed in Table 1) on the cancer-specific survival by means of univariate analyses (Table 2). As expected, older age was associated with a reduced median survival $(P=0.0004)$; macroscopically complete resection (based on radiology reports of first postoperative imaging) significantly improved the median survival of the patients (from 8.4 to 13.1 months; $P=0.002$ ), as did the addition of TMZ to radiotherapy (from 10.6 to 14.9 months; $\left.P=10^{-5}\right)$. No association was found between the quantitative immunostaining evaluation of the expression of IGFI, IGFII or IGF-IIR and the patient outcomes. In contrast, IGF-IR LI was negatively associated with cancer-specific survival $(P=0.046)$. We also evaluated the prognostic impact of these four markers after binarising the data (negative/positive, as described in Materials and Methods). Similar to the results of the quantitative immunostaining evaluation, only positive expression of IGF-IR was associated with significantly reduced survival, as shown in Figure $3 \mathrm{~A}$ $(P=0.02)$. Interestingly, when the IGF-IR expression was categorised into three groups (i.e., negative, weakly positive and strongly positive), the median survival of patients with strong expression of IGF-IR was observed to be dramatically reduced (4.5 months) compared with that of the GBM IGF-IR-negative patients (11.6 months) (three-group comparison $P=0.01$; negative vs strongly positive $P=0.007$; Figure $3 \mathrm{~B}$ ). A multivariate Cox regression analysis was then performed to test the prognostic contribution of IGF-IR expression in the presence of the prognostic clinical factors, that is, those for which the univariate results were significant (see Table 2). This model was established using 167 cases (excluding cases with missing values and the non-standard treatment category, see Table 1 ). We previously verified that the univariate results shown in Table 2 remain valid with this reduced series (except that the quantitative IGF-IR LI variable slightly lost in significance with $P=0.057$ ), without impacting the selection of variables introduced in the Cox model. As detailed in Table 3, IGF-IR-positive staining $(P=0.016)$ as well as older age $(P=0.003)$, macroscopically partial resection $(P=0.039)$ and radiotherapy alone $(P=0.003)$ were independent prognostic factors associated with shorter survival.

IGF-IR expression modulates the response to adjuvant treatment. To examine whether IGF-IR expression correlates with the response to adjuvant treatment, we evaluated the efficacy of adding TMZ to radiotherapy in two distinct groups of GBM patients (IGF-IR-negative, i.e., $\mathrm{LI}<1 \%$ and IGF-IR-positive, i.e., $\mathrm{LI} \geqslant 1 \%$ ). As shown in Figures $3 \mathrm{C}$ and $\mathrm{D}$, the addition of TMZ to radiotherapy significantly improved the survival of GBM patients compared with that of patients receiving only radiotherapy in both groups (IGF-IR-negative: $n=61, P=0.002$; IGF-IR positive: $n=107, P=0.007)$. However, the benefit of TMZ seems more important in the IGF-IR-negative group (Figure 3C). Indeed, this latter group showed a mortality risk reduction of $83 \%$ associated with the addition of TMZ (hazard ratio of 0.17 ), whereas the 

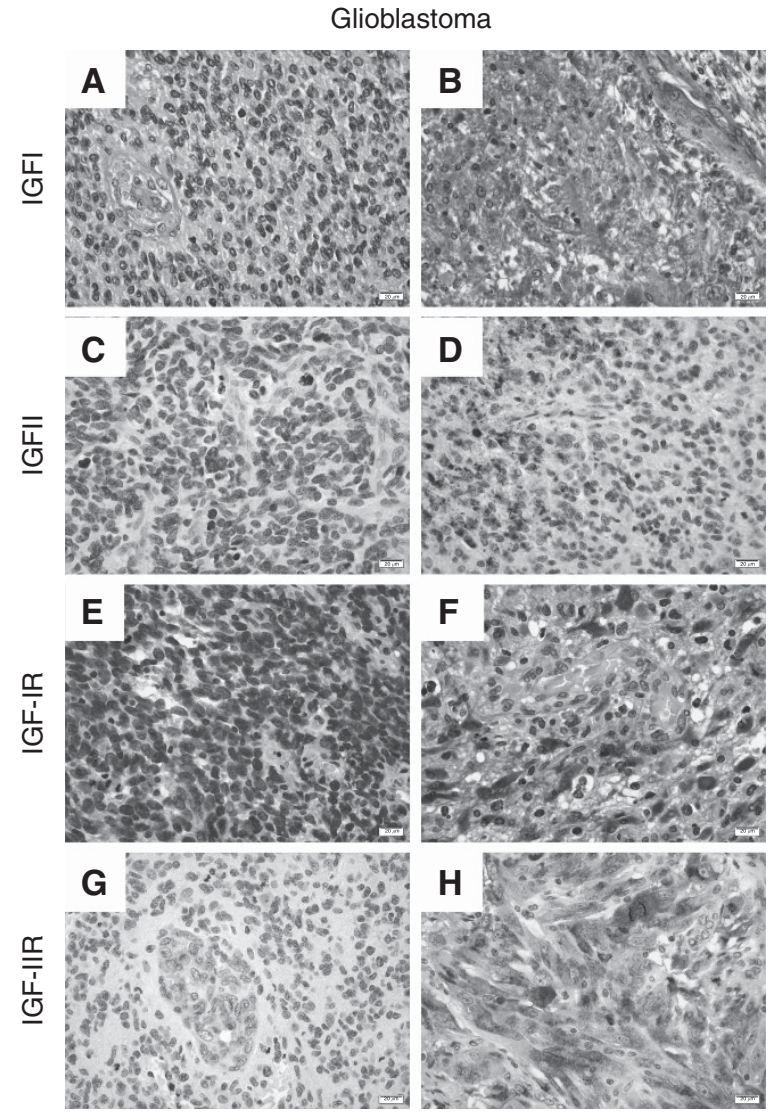

Figure 2. Immunohistochemical expression levels of IGFI (A and B), IGFII (C and D), IGF-IR ( $\mathbf{E}$ and $\mathbf{F}$ ) and IGF-IIR ( $\mathbf{G}$ and $\mathbf{H}$ ) in glioblastomas. Original magnification $\times 400$, scale bars $=20 \mu \mathrm{m}$.

reduction was less $(60 \%)$ in the IGF-IR-positive group (hazard ratio of 0.40 ). These data suggested that IGF-IR expression in GBMs might be associated with chemoresistance to TMZ.

\section{DISCUSSION}

Abundant data from cell cultures, animal models and human epidemiological studies suggest that the IGF system is implicated in the development of malignancies, including GBM (Pollak, 2004; Lonn et al, 2008). However, data on the expression of the members of the IGF system in GBM are limited and conflicting.

In the current study, we examined the expression of IGFI, IGFII, IGF-IR and IGF-IIR in the normal brain and in a large series of GBMs and correlated the results with clinical data. We detected IGFI expression in 25\% of GBMs. This result is not consistent with those of previous studies (Antoniades et al, 1992; SandbergNordqvist et al, 1993; Hirano et al, 1999). The discrepancy could be due essentially to the small number of immunohistochemically analysed cases in the other studies, that is, between 2 and 17 GBM samples, making the estimation of the proportions of positive cases less accurate. In contrast, we analysed 212 cases, that is, a series which better covers the known heterogeneity of GBMs and makes our estimation more accurate. Moreover, different primary antibodies were used across the different studies.

In the present work, while approximately $20 \%$ of the GBM cases were positive for the IGF ligands (IGFI and/or IGFII), most of them expressed the IGF receptors. IGF-IR and IGF-IIR staining was detected in the cytoplasm of the tumour cells. Although it would have been preferable to compare expression in the normal brain and GBM from the same patients, we noticed that IGF-IR
Table 2. Univariate survival analyses

\begin{tabular}{|c|c|c|}
\hline & $\begin{array}{l}\text { Median cancer-specific } \\
\text { survival (months) }\end{array}$ & $P$-value \\
\hline Age (years)* $(n=218)$ & & 0.0004 \\
\hline Multifocality $(n=207)$ & & NS \\
\hline $\begin{array}{l}\text { No } \\
\text { Yes }\end{array}$ & $\begin{array}{r}7.9 \\
10.6\end{array}$ & \\
\hline Date of surgery* $(n=218)$ & & NS \\
\hline Surgical resection $(n=203)$ & & 0.002 \\
\hline $\begin{array}{l}\text { Partial } \\
\text { Complete }\end{array}$ & $\begin{array}{r}8.4 \\
13.1\end{array}$ & \\
\hline Adjuvant therapy $(n=168)$ & & $10^{-5}$ \\
\hline $\begin{array}{l}\text { Radiotherapy } \\
\text { Radiotherapy }+ \text { temozolomide }\end{array}$ & $\begin{array}{l}10.6 \\
14.9\end{array}$ & \\
\hline IGFI LI* $(n=212)$ & & NS \\
\hline IGFII LI* $(n=204)$ & & NS \\
\hline IGF-IR LI* $(n=218)$ & & 0.046 \\
\hline IGF-IIR LI* $(n=213)$ & & NS \\
\hline \multicolumn{3}{|l|}{ Binary scores } \\
\hline $\begin{array}{l}\text { IGFI }(n=212) \\
\text { Positive } \\
\text { Negative }\end{array}$ & $\begin{array}{r}8.7 \\
10.5\end{array}$ & NS \\
\hline $\begin{array}{l}\text { IGFII }(n=204) \\
\text { Positive } \\
\text { Negative }\end{array}$ & $\begin{array}{l}8.8 \\
9.3\end{array}$ & NS \\
\hline $\begin{array}{l}\text { IGF-IR }(n=218) \\
\text { Positive } \\
\text { Negative }\end{array}$ & $\begin{array}{r}9.0 \\
11.6\end{array}$ & 0.020 \\
\hline $\begin{array}{l}\text { IGF-IIR ( } n=213 \text { ) } \\
\text { Positive } \\
\text { Negative }\end{array}$ & $\begin{array}{r}10.3 \\
9.2\end{array}$ & NS \\
\hline \multicolumn{3}{|c|}{$\begin{array}{l}\text { Abbreviations: IGF = insulin-like growth factor; } \mathrm{LI}=\text { labelling index; } \mathrm{NS}=\text { not significant. } \\
\text { Continuous variables were analysed using the univariate Cox regression (see asterisk (*)). } \\
\text { The other binary variables were analysed using the log-rank test. For these latter variables, } \\
\text { each category is characterised by the median cancer-specific survival time (in months). For } \\
\text { IGFI, IGFII, IGF-IR and IGF-IIR, the cases labelled as positive correspond to } \mathrm{LI} \geqslant 1 \% \text { and } \\
\text { those labelled as negative to } \mathrm{L}<1 \% \text {. The } n \text { values indicate the total number of cases taken } \\
\text { into account in the univariate analyses (excluding the missing values and certain non- } \\
\text { standard clinical categories that are detailed in Table } 1 \text { ). }\end{array}$} \\
\hline
\end{tabular}

and IGF-IIR are overexpressed in GBM compared with normal brain tissue. Interestingly, we observed cytoplasmic dot-like staining of IGF-IIR in endothelial cells, particularly in tumour microvessels exhibiting endothelial proliferation. This pattern of expression suggests that IGF-IIR could be involved in angiogenesis. This hypothesis, which is supported by several in vitro studies indicating a pro-angiogenic effect of IGF-IIR through interactions with G proteins (Groskopf et al, 1997; Herr et al, 2003; Maeng et al, 2009), will be investigated in future work.

With regard to the colocation of ligand and receptor expression in GBM samples, while the majority of IGFI-positive cores was IGF-IR positive, IGFII was more often located with IGF-IIR. This data can be related to the high affinity of IGF-IR for both IGFI and IGFII, whereas IGF-IIR binds IGFII with high affinity but IGFI with very low affinity (Denley et al, 2005; Sachdev and Yee, 2007). Moreover, it is interesting to note that many cores expressed both receptors and that most of the observed IGFII positivity was located in perinecrotic areas, consistent with reports that IGFII expression is upregulated by hypoxia (Feldser et al, 1999; Mohlin et al, 2013). Concerning the clinical impact, we observed that, among the different IGF members, only IGF-IR expression has a prognostic value, being negatively associated with cancerspecific survival. Various studies have evaluated the prognostic significance of IGF-IR expression in other cancers. Although conflicting data were reported concerning breast (Railo et al, 1994; Fu et al, 2011; Hartog et al, 2011) and lung (Ludovini et al, 2009; 
A

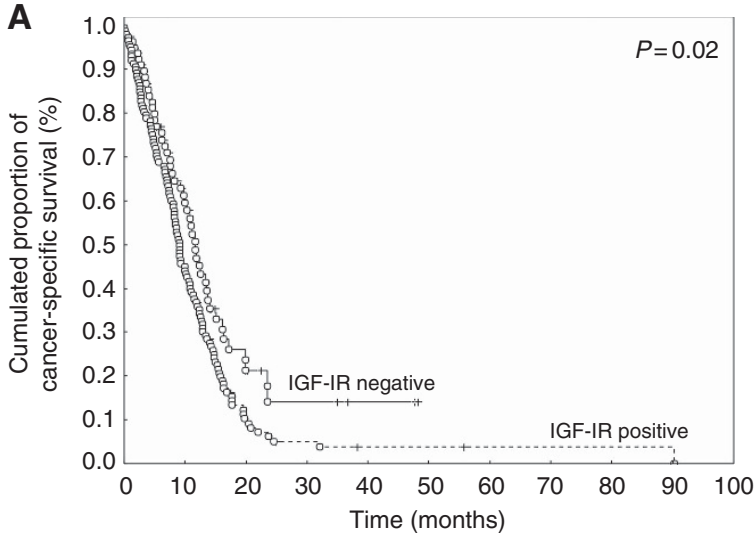

C

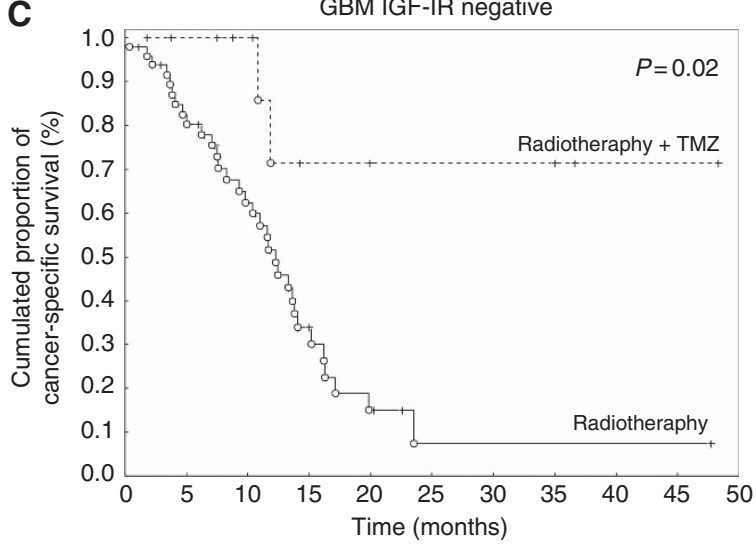

B

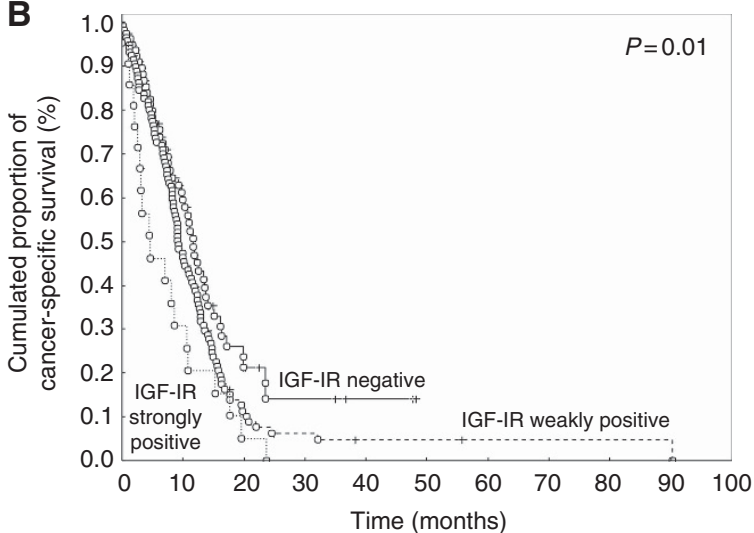

D

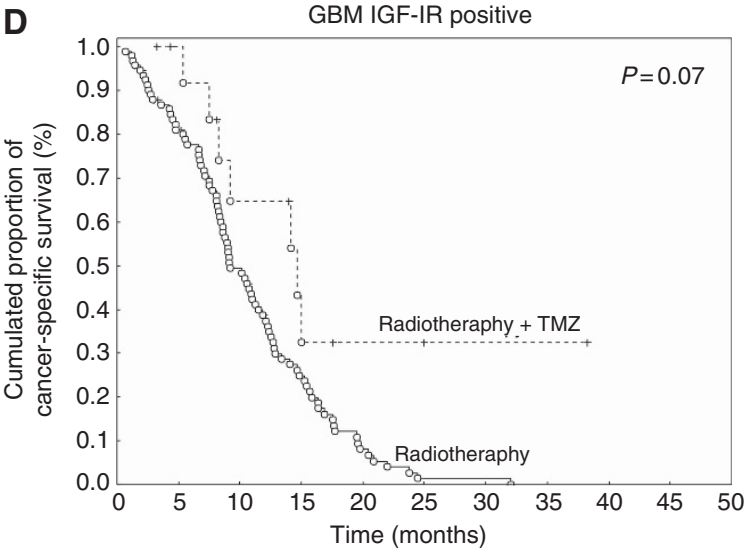

Figure 3. Kaplan-Meier survival curves of GBM patients according to the IGF-IR expression categorised as (A) negative (i.e., LI<1\%) or positive (i.e., $\mathrm{LI} \geqslant 1 \%$ ); (B) negative (i.e., $\mathrm{LI}<1 \%$ ), weakly positive (i.e., $1 \% \leqslant \mathrm{LI}<30 \%$ ) or strongly positive (i.e., $\mathrm{LI} \geqslant 30 \%$ ), and Kaplan-Meier survival curves of GBM patients according to the adjuvant treatment in IGF-IR-negative (i.e., LI<1\%) (C) or IGF-IR-positive (i.e., LI $\geqslant 1 \%$ ) (D) cases. Each dot symbolises a death due to cancer and each cross indicates a survivor or a death not related to cancer (censured data).

Table 3. Cox regression model $(n=167)$

\begin{tabular}{|l|l|c|c|c|}
\hline Model/P-value & \multicolumn{1}{|c|}{ Prognostic factors } & Hazard ratio & $\mathbf{9 5 \%} \mathrm{Cl}$ & $\mathbf{P}$-value \\
\hline$<10^{-5}$ & Age & 1.02 & $1.01-1.04$ & 0.003 \\
\hline & Complete resection & 0.67 & $0.45-0.98$ & 0.039 \\
\hline & Radiotherapy + temozolomide & 0.35 & $0.17-0.70$ & 0.003 \\
\hline & IGF-IR positive & 1.65 & $1.10-2.47$ & 0.016 \\
\hline
\end{tabular}

Abbreviations: $\mathrm{Cl}=$ confidence interval; IGF = insulin-like growth factor. The 'Model/P-value' indicates the overall level of significance of the multivariate model. With the exception of 'Age', which is a quantitative variable, all of the others are binary. Resection distinguishes between partial and complete, adjuvant treatment between radiotherapy and radiotherapy + temozolomide and IGF-IR between positive $(L I \geqslant 1 \%)$ and negative $(L I<1 \%)$. The individual $P$-values represent the levels of significance of the independent contributions of each factor.

Cappuzzo et al, 2010) cancers, this biomarker is associated with a poor outcome in patients with oesophageal, gastric, oral or cervical carcinomas (Imsumran et al, 2007; Matsubara et al, 2008; Kalinina et al, 2010; Henriquez-Hernandez et al, 2011; Lara et al, 2011). So far, only one study has evaluated the prognostic impact of IGF-IR expression in GBM: using the Repository of Molecular Brain Neoplasia Data (REMBRANDT) of the National Cancer Institute, authors showed that GBM patients with upregulation of IGF-IR at the gene level carry a significantly worse prognosis than patients with relative downregulation of IGF-IR. They confirmed this inverse correlation between IGF-IR gene expression levels and survival at the protein level using a TMA of GBM samples (Zamykal et al, 2014). Our study confirms these data on a larger series of GBM. Furthermore, in our multivariate Cox regression, IGF-IR positivity was identified as an independent prognostic factor.
Currently, the standard treatment for GBM consists of maximal surgical resection, radiotherapy and concomitant and adjuvant TMZ chemotherapy (Stupp et al, 2009). TMZ is an alkylating agent that induces the formation of $\mathrm{O}^{6}$-methylguanine in DNA, which mispairs with thymidine during the following cycle of DNA replication, leading to the activation of apoptotic pathways (Darkes et al, 2002). Other mechanisms of action have also been described such as the induction of G2-M arrest or autophagy (Hirose et al, 2001; Kanzawa et al, 2004). Although the improvement in median survival caused by the addition of $\mathrm{TMZ}$ to radiotherapy is significant, it remains modest (Stupp et al, 2009). Indeed, there are inherent and acquired resistances conferred by multiple mechanisms (Zhang et al, 2012) such as the lack of expression of the DNA repair enzyme $\mathrm{O}^{6}$-guanine-DNA-methyl transferase, deficiencies in DNA mismatch repair and initiation of the base excision repair 
system (Johannessen and Bjerkvig, 2012). In this context of resistance to TMZ, our study suggests that IGF-IR expression in GBM could be correlated with the response to adjuvant treatment. Nevertheless, it should be noted that these results might be interpreted with caution because of the small patients number in this subgroup analysis. Anyway other therapeutic modalities are needed.

IGF-IR is considered as a potential therapeutic target in cancer (Hewish et al, 2009). As reviewed by Trojan et al in 2007, multiple investigations targeting IGF-IR in GBM demonstrated antineoplastic activity in in vitro and in vivo models (Trojan et al, 2007). In the in vivo models, downregulation of IGF-IR using an antisense strategy (Resnicoff et al, 1994), triple-helix strategy (Rininsland et al, 1997), inhibitors such as picropodophyllin (Yin et $a l, 2010$ ) or a dominant-negative mutant (D'Ambrosio et al, 1996) resulted in inhibition of tumour growth. Inhibition of IGF-IR causes apoptosis of tumour cells, inhibition of tumorigenesis and an immune antitumour response. All of these data motivated the first clinical trial involving the use of an antisense IGF-IR strategy for 12 patients with recurrent GBM or anaplastic astrocytoma (Andrews et al, 2001). This treatment was associated with a rather high rate of clinical and radiological improvement with two complete responses and four partial responses achieved. More recently, Zamykal et al (2014) investigated the effect of the IGF-IR blocking antibody IMC-A12 on in vivo GBM growth. They confirmed that IGF-IR may be an interesting therapeutic target in GBM.

Currently, there is a phase I/IIa study to investigate the safety, tolerability and antitumour efficacy of AXL1717 (picropodophyllin as an active agent formulated in an oral suspension) in patients with recurrent malignant astrocytomas (www.clinicaltrials.gov). Furthermore, studies in other tumour types have demonstrated that NVP-AEW541, a pyrrolo [2,3-d]pyrimidine derivative small molecular weight kinase inhibitor of the IGF-IR (with a high selectivity: IC50 $=0.086 \mu \mathrm{M}) \quad($ Garcia-Echeverria et al, 2004), produces synergistic growth inhibition when combined with other chemotherapeutic agents (Gotlieb et al, 2006; Mukohara et al, 2009).

Literature data provide clear evidence that GBMs constitute a heterogeneous group of tumours. In 2006, Philipps et al used gene expression to divide GBMs into 3 groups (i.e., proneural, proliferative and mesenchymal), which are associated with different prognoses (Phillips et al, 2006). In 2007, Soroceanu et al showed that IGFII is overexpressed in the proliferative group, which is characterised by a poor survival (Soroceanu et al, 2007). Verhaak et al (2010) proposed classifying GBMs into four groups (i.e., classical, mesenchymal, proneural and neural) based on genomic abnormalities such as IDH1 mutation, EGFR amplification, p53 mutation, NF1 deletion or mutation and PDGFRA amplification. These subtypes were associated with different responses to therapy. A recent study conducted in our laboratory defined a simplified classification based on immunohistochemistry. With this method, we identified two clinically relevant subtypes of GBM: the 'Classical-like subtype' (CL) characterised by EGFRpositive, p53-negative and PDGFRA-negative staining and the 'Proneural-like subtype' (PNL) characterised by p53- and/or PDGFRA-positive staining. The addition of TMZ to radiotherapy significantly improved the survival of patients with GBMs of the CL subtype but did not affect the survival of patients with GBMs of the PNL subtype (Le Mercier et al, 2012). Because 70 patients were common between the previous study and the present work, we evaluated whether IGF-IR expression is related to this recent classification system. Interestingly, the proportion of IGF-IRpositive cases was significantly higher in the PNL subtype (for which the addition of TMZ was evidenced as being ineffective), compared with the CL subtype (PNL: 31 out of 44, i.e., $70 \%$ vs CL: 12 out of 26 , i.e., $46 \% ; P=0.04)$.
In conclusion, IGF-IR is overexpressed in the majority of GBMs compared with the normal brain. With regard to standard clinical factors, this overexpression is associated with an independent prognostic value in terms of cancer-specific survival and a less favourable response to TMZ. Our data suggest that IGF-IR could be an interesting target for GBM therapy. Additional studies are, however, needed to investigate the role of IGF-IR in the chemoresistance of GBMs and to determine which patients could benefit from combination therapy with TMZ and an IGF-IR inhibitor.

\section{ACKNOWLEDGEMENTS}

CD is a Senior Research Associate with the 'Fonds National de la Recherche Scientifique' (Brussels, Belgium). This work was supported by a doctoral grant from the 'Fonds National de la Recherche Scientifique' (to CM), the Fonds Erasme (to ALT) and by the Fonds Yvonne Boël (Brussels, Belgium). The CMMI is supported by the European Regional Development Fund and the Walloon Region.

\section{CONFLICT OF INTEREST}

The authors declare no conflict of interest.

\section{REFERENCES}

Andrews DW, Resnicoff M, Flanders AE, Kenyon L, Curtis M, Merli G, Baserga R, Iliakis G, Aiken RD (2001) Results of a pilot study involving the use of an antisense oligodeoxynucleotide directed against the insulin-like growth factor type I receptor in malignant astrocytomas. J Clin Oncol 19: 2189-2200.

Antoniades HN, Galanopoulos T, Neville-Golden J, Maxwell M (1992) Expression of insulin-like growth factors I and II and their receptor mRNAs in primary human astrocytomas and meningiomas; in vivo studies using in situ hybridization and immunocytochemistry. Int $J$ Cancer 50: $215-222$.

Battifora H (1991) Assessment of antigen damage in immunohistochemistry. The vimentin internal control. Am J Clin Pathol 96: 669-671.

Bondy ML, Scheurer ME, Malmer B, Barnholtz-Sloan JS, Davis FG, Il'yasova D, Kruchko C, McCarthy BJ, Rajaraman P, Schwartzbaum JA, Sadetzki S, Schlehofer B, Tihan T, Wiemels JL, Wrensch M, Buffler PA. Brain Tumor Epidemiology Consortium (2008) Brain tumor epidemiology: consensus from the Brain Tumor Epidemiology Consortium. Cancer 113: 1953-1968.

Brockmann MA, Ulbricht U, Gruner K, Fillbrandt R, Westphal M, Lamszus K (2003) Glioblastoma and cerebral microvascular endothelial cell migration in response to tumor-associated growth factors. Neurosurgery 52: 1391-1399.

Cappuzzo F, Tallini G, Finocchiaro G, Wilson RS, Ligorio C, Giordano L, Toschi L, Incarbone M, Cavina R, Terracciano L, Roncalli M, Alloisio M, Varella-Garcia M, Franklin WA, Santoro A (2010) Insulin-like growth factor receptor 1 (IGF1 R) expression and survival in surgically resected non-small-cell lung cancer (NSCLC) patients. Ann Oncol 21: 562-567.

D’Ambrosio C, Ferber A, Resnicoff M, Baserga R (1996) A soluble insulin-like growth factor I receptor that induces apoptosis of tumor cells in vivo and inhibits tumorigenesis. Cancer Res 56: 4013-4020.

Darkes MJM, Plosker GL, Jarvis B (2002) Temozolomide. A review of its use in the treatment of malignant gliomes, malignant melanoma and other advanced cancers. Am J Cancer 1: 55-80.

Decaestecker C, Lopez XM, D’Haene N, Roland I, Guendouz S, Duponchelle C, Berton A, Debeir O, Salmon I (2009) Requirements for the valid quantification of immunostains on tissue microarray materials using image analysis. Proteomics 9: 4478-4494.

Denley A, Cosgrove LJ, Booker GW, Wallace JC, Forbes BE (2005) Molecular interactions of the IGF system. Cytokine Growth Factor Rev 16: 421-439. 
Feldser D, Agani F, Iyer NV, Pak B, Ferreira G, Semenza GL (1999) Reciprocal positive regulation of hypoxia-inducible factor $1 \alpha$ and insulin-like growth factor 2. Cancer Res 59: 3915-3918.

Friend KE, Khandwala HM, Flyvbjerg A, Hill H, Li J, McCutcheon IE (2001) Growth hormone and insulin-like growth factor-I: effects on the growth of glioma cell lines. Growth Horm IGF Res 11: 84-91.

Fu P, Ibusuki M, Yamamoto Y, Yamamoto S, Fujiwara S, Murakami K, Zheng S, Iwase H (2011) Quantitative determination of insulin-like growth factor 1 receptor mRNA in formalin-fixed paraffin-embedded tissues of invasive breast cancer. Breast Cancer 19: 321-328.

Garcia-Echeverria C, Pearson MA, Marti A, Meyer T, Mestan J, Zimmermann J, Gao J, Brueggen J, Capraro HG, Cozens R, Evans DB, Fabbro D, Furet P, Porta DG, Liebetanz J, Martiny-Baron G, Ruetz S, Hofmann F (2004) In vivo antitumor activity of NVP-AEW541-A novel, potent, and selective inhibitor of the IGF-IR kinase. Cancer Cell 5: 231-239.

Glick RP, Gettleman R, Patel K, Lakshman R, Tsibris JC (1989) Insulin and insulin-like growth factor I in brain tumors: binding and in vitro effects. Neurosurgery 24: 791-797.

Gotlieb WH, Bruchim I, Gu J, Shi Y, Camirand A, Blouin MJ, Zhao Y, Pollak MN (2006) Insulin-like growth factor receptor I targeting in epithelial ovarian cancer. Gynecol Oncol 100: 389-396.

Groskopf JC, Syu LJ, Saltiel AR, Linzer DI (1997) Proliferin induces endothelial cell chemotaxis through a G protein-coupled, mitogenactivated protein kinase-dependent pathway. Endocrinology 138: 2835-2840.

Guvakova MA (2007) Insulin-like growth factors control cell migration in health and disease. Int J Biochem Cell Biol 39: 890-909.

Hameed O, Adams AL, Baker AC, Balmer NE, Bell WC, Burford HN, Chhieng DC, Jhala NC, Klein MJ, Winokur T (2008) Using a higher cutoff for the percentage of HER $2+$ cells decreases interobserver variability in the interpretation of HER2 immunohistochemical analysis. Am J Clin Pathol 130: 425-427.

Hartog H, Horlings HM, van der Vegt B, Kreike B, Ajouaou A, van de Vijver MJ, Marike Boezen H, de Bock GH, van der Graaf WT, Wesseling J (2011) Divergent effects of insulin-like growth factor-1 receptor expression on prognosis of estrogen receptor positive versus triple negative invasive ductal breast carcinoma. Breast Cancer Res Treat 129: $725-736$.

Henriquez-Hernandez LA, Lloret M, Pinar B, Bordón E, Rey A, Lubrano A, Lara PC (2011) BCL-2, in combination with MVP and IGF-1 R expression, improves prediction of clinical outcome in complete response cervical carcinoma patients treated by radiochemotherapy. Gynecol Oncol 122: 585-589.

Herr F, Liang OD, Herrero J, Lang U, Preissner KT, Han VK, Zygmunt M (2003) Possible angiogenic roles of insulin-like growth factor II and its receptors in uterine vascular adaptation to pregnancy. J Clin Endocrinol Metab 88: 4811-4817.

Hewish M, Chau I, Cunningham D (2009) Insulin-like growth factor 1 receptor targeted therapeutics: novel compounds and novel treatment strategies for cancer medicine. Recent Pat Anticancer Drug Discov 4 : $54-72$.

Hirano H, Lopes MB, Laws ER, Asakura T, Goto M, Carpenter JE, Karns LR, VandenBerg SR (1999) Insulin-like growth factor-1 content and pattern of expression correlates with histopathologic grade in diffusely infiltrating astrocytomas. Neuro Oncol 1: 109-119.

Hirose Y, Berger MS, Pieper RO (2001) Abrogation of the Chk1-mediated $\mathrm{G}(2)$ checkpoint pathway potentiates temozolomide-induced toxicity in a p53-independent manner in human glioblastoma cells. Cancer Res 61: 5843-5849.

Imsumran A, Adachi Y, Yamamoto H, Li R, Wang Y, Min Y, Piao W, Nosho K, Arimura Y, Shinomura Y, Hosokawa M, Lee CT, Carbone DP, Imai K (2007) Insulin-like growth factor-I receptor as a marker for prognosis and a therapeutic target in human esophageal squamous cell carcinoma. Carcinogenesis 28: 947-956.

Johannessen TC, Bjerkvig R (2012) Molecular mechanisms of temozolomide resistance in glioblastoma multiforme. Expert Rev Anticancer Ther 12: 635-642.

Kalinina T, Bockhorn M, Kaifi JT, Thieltges S, Güngör C, Effenberger KE, Strelow A, Reichelt U, Sauter G, Pantel K, Izbicki JR, Yekebas EF (2010) Insulin-like growth factor-1 receptor as a novel prognostic marker and its implication as a cotarget in the treatment of human adenocarcinoma of the esophagus. Int J Cancer 127: 1931-1940.
Kanzawa T, Germano IM, Komata T, Ito H, Kondo Y, Kondo S (2004) Role of autophagy in temozolomide-induced cytotoxicity for malignant glioma cells. Cell Death Differ 11: 448-457.

Lara PC, Bordon E, Rey A, Moreno M, Lloret M, Henríquez-Hernández LA (2011) IGF-1 R expression predicts clinical outcome in patients with locally advanced oral squamous cell carcinoma. Oral Oncol 47: 615-619.

Le Mercier M, Hastir D, Moles Lopez X, De Nève N, Maris C, Trepant AL, Rorive S, Decaestecker C, Salmon I (2012) A simplified approach for the molecular classification of glioblastomas. PloS One 7: e45475.

Le Roith D (2003) The insulin-like growth factor system. Exp Diabesity Res 4 : 205-212.

Lonn S, Rothman N, Shapiro WR, Fine HA, Selker RG, Black PM, Loeffler JS, Hutchinson AA, Inskip PD (2008) Genetic variation in insulin-like growth factors and brain tumor risk. Neuro Oncol 10: 553-559.

Louis DN, Ohgaki H, Wiestler OD, Cavenee WK (2007) WHO Classification of Tumours of the Central Nervous System, 3rd edn. International Agency for Research on Cancer: Lyon, France, pp 33-49.

Ludovini V, Bellezza G, Pistola L, Bianconi F, Di Carlo L, Sidoni A, Semeraro A, Del Sordo R, Tofanetti FR, Mameli MG, Daddi G, Cavaliere A, Tonato M, Crinò L (2009) High coexpression of both insulin-like growth factor receptor-1 (IGFR-1) and epidermal growth factor receptor (EGFR) is associated with shorter disease-free survival in resected non-small-cell lung cancer patients. Ann Oncol 20: 842-849.

Maeng YS, Choi HJ, Kwon JY, Park YW, Choi KS, Min JK, Kim YH, Suh PG, Kang KS, Won MH, Kim YM, Kwon YG (2009) Endothelial progenitor cell homing: prominent role of the IGF2-IGF2R-PLCbeta2 axis. Blood 113: 233-243.

Matsubara J, Yamada Y, Hirashima Y, Takahari D, Okita NT, Kato K, Hamaguchi T, Shirao K, Shimada Y, Shimoda T (2008) Impact of insulin-like growth factor type 1 receptor, epidermal growth factor receptor, and HER2 expressions on outcomes of patients with gastric cancer. Clin Cancer Res 14: 3022-3029.

Merrill MJ, Edwards NA (1990) Insulin-like growth factor-I receptors in human glial tumors. J Clin Endocrinol Metab 71: 199-209.

Mohlin S, Hamidian A, Pahlman S (2013) HIF2A and IGF2 expression correlates in human neuroblastoma cells and normal immature sympathetic neuroblasts. Neoplasia 15: 328-334.

Mukohara T, Shimada H, Ogasawara N, Wanikawa R, Shimomura M, Nakatsura T, Ishii G, Park JO, Jänne PA, Saijo N, Minami H (2009) Sensitivity of breast cancer cell lines to the novel insulin-like growth factor-1 receptor (IGF-1R) inhibitor NVP-AEW541 is dependent on the level of IRS-1 expression. Cancer Lett 282: 14-24.

Phillips HS, Kharbanda S, Chen R, Forrest WF, Soriano RH, Wu TD, Misra A, Nigro JM, Colman H, Soroceanu L, Williams PM, Modrusan Z, Feuerstein BG, Aldape K (2006) Molecular subclasses of high-grade glioma predict prognosis, delineate a pattern of disease progression, and resemble stages in neurogenesis. Cancer Cell 9: 157-173.

Pollak MN (2004) Insulin-like growth factors and neoplasia. Novartis Found Symp 262: 84-98.

Railo MJ, von Smitten K, Pekonen F (1994) The prognostic value of insulinlike growth factor-I in breast cancer patients. Results of a follow-up study on 126 patients. Eur J Cancer 30A: 307-311.

Resnicoff M, Sell C, Rubini M, Coppola D, Ambrose D, Baserga R, Rubin R (1994) Rat glioblastoma cells expressing an antisense RNA to the insulinlike growth factor-1 (IGF-1) receptor are nontumorigenic and induce regression of wild-type tumors. Cancer Res 54: 2218-2222.

Rininsland F, Johnson TR, Chernicky CL, Schulze E, Burfeind P, Ilan J (1997) Suppression of insulin-like growth factor type I receptor by a triple-helix strategy inhibits IGF-I transcription and tumorigenic potential of rat C6 glioblastoma cells. Proc Natl Acad Sci USA 94: 5854-5859.

Rorive S, Berton A, D'Haene N, Takacs CN, Debeir O, Decaestecker C, Salmon I (2008) Matrix metalloproteinase-9 interplays with the IGFBP2-IGFII complex to promote cell growth and motility in astrocytomas. Glia 56: 1679-1690.

Rorive S, Lopez XM, Maris C, Trepant AL, Sauvage S, Sadeghi N, Roland I, Decaestecker C, Salmon I (2010) TIMP-4 and CD63: new prognostic biomarkers in human astrocytomas. Mod Pathol 23: $1418-1428$.

Sachdev D, Yee D (2007) Disrupting insulin-like growth factor signaling as a potential cancer therapy. Mol Cancer Ther 6: 1-12.

Samani AA, Yakar S, LeRoith D, Brodt P (2007) The role of the IGF system in cancer growth and metastasis: overview and recent insights. Endocr Rev 28: $20-47$. 
Sandberg-Nordqvist AC, Stahlbom PA, Reinecke M, Collins VP, von Holst H, Sara V (1993) Characterization of insulin-like growth factor 1 in human primary brain tumors. Cancer Res 53: 2475-2478.

Schlenska-Lange A, Knupfer H, Lange TJ, Kiess W, Knüpfer M (2008) Cell proliferation and migration in glioblastoma multiforme cell lines are influenced by insulin-like growth factor I in vitro. Anticancer Res 28: 1055-1060.

Soroceanu L, Kharbanda S, Chen R, Soriano RH, Aldape K, Misra A, Zha J, Forrest WF, Nigro JM, Modrusan Z, Feuerstein BG, Phillips HS (2007) Identification of IGF2 signaling through phosphoinositide-3-kinase regulatory subunit 3 as a growth-promoting axis in glioblastoma. Proc Natl Acad Sci USA 104: 3466-3471.

Stupp R, Hegi ME, Mason WP, van den Bent MJ, Taphoorn MJ, Janzer RC, Ludwin SK, Allgeier A, Fisher B, Belanger K, Hau P, Brandes AA, Gijtenbeek J, Marosi C, Vecht CJ, Mokhtari K, Wesseling P, Villa S, Eisenhauer E, Gorlia T, Weller M, Lacombe D, Cairncross JG, Mirimanoff RO. European Organisation for Research and Treatment of Cancer Brain Tumour and Radiation Oncology GroupsNational Cancer Institute of Canada Clinical Trials Group (2009) Effects of radiotherapy with concomitant and adjuvant temozolomide versus radiotherapy alone on survival in glioblastoma in a randomised phase III study: 5-year analysis of the EORTC-NCIC trial. Lancet Oncol 10: 459-466.

Suvasini R, Shruti B, Thota B, Shinde SV, Friedmann-Morvinski D, Nawaz Z, Prasanna KV, Thennarasu K, Hegde AS, Arivazhagan A, Chandramouli BA, Santosh V, Somasundaram K (2011) Insulin growth factor-2 binding protein 3 (IGF2BP3) is a glioblastoma-specific marker that activates phosphatidylinositol 3-kinase/mitogen-activated protein kinase (PI3K/MAPK) pathways by modulating IGF-2. J Biol Chem 286: 25882-25890.
Trojan J, Cloix JF, Ardourel MY, Chatel M, Anthony DD (2007) Insulin-like growth factor type I biology and targeting in malignant gliomas. Neuroscience 145: 795-811.

Verhaak RG, Hoadley KA, Purdom E, Wang V, Qi Y, Wilkerson MD, Miller CR, Ding L, Golub T, Mesirov JP, Alexe G, Lawrence M, O’Kelly M, Tamayo P, Weir BA, Gabriel S, Winckler W, Gupta S, Jakkula L, Feiler HS, Hodgson JG, James CD, Sarkaria JN, Brennan C, Kahn A, Spellman PT, Wilson RK, Speed TP, Gray JW, Meyerson M, Getz G, Perou CM, Hayes DN. Cancer Genome Atlas Research Network (2010) Integrated genomic analysis identifies clinically relevant subtypes of glioblastoma characterized by abnormalities in PDGFRA, IDH1, EGFR, and NF1. Cancer Cell 17: 98-110.

Yin S, Girnita A, Stromberg T, Khan Z, Andersson S, Zheng H, Ericsson C, Axelson M, Nistér M, Larsson O, Ekström TJ, Girnita L (2010) Targeting the insulin-like growth factor-1 receptor by picropodophyllin as a treatment option for glioblastoma. Neuro Oncol 12: 19-27.

Zamykal M, Martens T, Matschke J, Günther HS, Kathagen A, Schulte A, Peters R, Westphal M, Lamszus K (2014) Inhibition of intracerebral glioblastoma growth by targeting the insulin-like growth factor 1 receptor involves different context-dependent mechanisms. Neuro Oncol; e-pub ahead of print 27 December 2014.

Zhang J, Stevens MF, Bradshaw TD (2012) Temozolomide: mechanisms of action, repair and resistance. Curr Mol Pharmacol 5: 102-114.

This work is published under the standard license to publish agreement. After 12 months the work will become freely available and the license terms will switch to a Creative Commons AttributionNonCommercial-Share Alike 4.0 Unported License 